\title{
Genetic parameters and estimated genetic gains in young rubber tree progenies
}

\author{
Cecília Khusala Verardi (1), Erivaldo José Scaloppi Junior ${ }^{(2)}$, Guilherme Augusto Peres Silva(1), \\ Lígia Regina Lima Gouvêa(1) and Paulo de Souza Gonçalves ${ }^{(1)}$
}

\begin{abstract}
(1)Instituto Agronômico, Caixa Postal 28, CEP 13012-970 Campinas, SP, Brazil. E-mail: ckverardi@yahoo.com.br, silva.gap@gmail.com, Igouvea@iac.sp.gov.br, paulog@iac.sp.gov (2)Agência Paulista de Tecnologia dos Agronegócios, Departamento de Descentralização do Desenvolvimento, Polo Regional Noroeste Paulista, Rodovia Péricles Belini, Km 121, Caixa Postal 61, CEP $15500-970$ Votuporanga, SP, Brazil. E-mail: scaloppi@apta.sp.gov.br
\end{abstract}

\begin{abstract}
The objective of this work was to assess the genetic parameters and to estimate genetic gains in young rubber tree progenies. The experiments were carried out during three years, in a randomized block design, with six replicates and ten plants per plot, in three representative Hevea crop regions of the state of São Paulo, Brazil. Twenty-two progenies were evaluated, from three to five years old, for rubber yield and annual girth growth. Genetic gain was estimated with the multi-effect index (MEI). Selection by progenies means provided greater estimated genetic gain than selection based on individuals, since heritability values of progeny means were greater than the ones of individual heritability, for both evaluated variables, in all the assessment years. The selection of the three best progenies for rubber yield provided a selection gain of $1.28 \mathrm{~g}$ per plant. The genetic gains estimated with MEI using data from early assessments (from 3 to 5 -year-old) were generally high for annual girth growth and rubber yield. The high genetic gains for annual girth growth in the first year of assessment indicate that progenies can be selected at the beginning of the breeding program. Population effective size was consistent with the three progenies selected, showing that they were not related and that the population genetic variability is ensured. Early selection with the genetic gains estimated by MEI can be made on rubber tree progenies.
\end{abstract}

Index terms: Hevea brasiliensis, annual girth growth, early selection, effective population size, multi-effect index, rubber yield.

\section{Parâmetros genéticos e ganhos de seleção estimados em progênies jovens de seringueira}

Resumo - O objetivo deste trabalho foi avaliar os parâmetros genéticos e estimar ganhos genéticos em progênies jovens de seringueira. Os experimentos foram realizados durante três anos, em delineamento de blocos ao acaso, com seis repetições e dez plantas por parcela, em três regiões representativas da heveicultura paulista. Vinte e duas progênies foram avaliadas, dos três aos cinco anos de idade, quanto à produção de borracha e incremento anual do caule. O ganho genético foi estimado com o índice multiefeitos (IME). A seleção pela média das progênies proporcionou maior ganho genético do que a seleção baseada em indivíduos, já que os valores de herdabilidade das médias de progênies foram maiores do que os da herdabilidade individual, para ambas as variáveis, em todos os anos de avaliação. A seleção das três melhores progênies quanto à produção de borracha proporcionou um ganho de seleção de 1,28 g por planta. Os ganhos genéticos estimados pelo IME com dados das primeiras avaliações (dos 3 aos 5 anos) foram altos em geral, para produção de borracha e incremento anual do caule. Os elevados ganhos genéticos obtidos para incremento anual no primeiro ano de avaliação indicam que as progênies podem ser selecionadas no início do programa de melhoramento. O tamanho efetivo da população foi condizente com as três progênies selecionadas e mostrou que elas não são aparentadas e que a variabilidade genética da população está garantida. A seleção precoce, com os ganhos genéticos estimados pelo IME, pode ser feita em progênies de seringueira.

Termos para indexação: Hevea brasiliensis, crescimento anual do caule, seleção precoce, tamanho efetivo populacional, índice multiefeito, produção de borracha.

\section{Introduction}

Breeding programs for rubber tree [Hevea brasiliensis (Willd. ex A. Juss.) Müell. Arg.] in Brazil have the main objective of uniting high yield and high vigor in a single individual. However, the breeding cycle of the species is very long, taking up to 30 years 
to achieve the final results. Therefore, research on young plants using early yield and plant vigor tests is very important.

Knowledge of the genetic variability of a population is the basis for breeding and essential to estimate the genetic parameters, which describe the variation levels among progenies, the magnitude of genetic control of traits, and the expected gains with selection (Freitas et al., 2006). Researches in several parts of the world, such as Indonesia, India, Malaysia, and Brazil, have been trying to maximize genetic gains of rubber tree (Costa et al., 2008) using different selection techniques in order to accelerate the breeding programs.

According to Resende et al. (1999) the multi-effect index (MEI) method is an excellent selection procedure, equivalent to the Blup (best linear unbiased prediction). MEI estimates uses the variances of the mixed linear model random effects when data are unbalanced or when survival is greater than $85 \%$. The index is based on the multiplication of phenotypic values of individuals, plot means, family means, block means, and general means by the weighing coefficients of the indexes (heritability). These coefficients are calculated in order to maximize the correlation between heritability indexes and genetic values. This maximization is obtained from the regression between genetic values and phenotype values. The multiplication between these values and coefficients is made using a matrix system (Resende \& Higa, 1994a). According to Resende \& Higa (1994b), selection based on MEI maximizes the genetic progress of a trait, regardless of the experimental structure.

The objective of this work was to assess the genetic parameters and estimate genetic gains in young rubber tree progenies.

\section{Materials and Methods}

The study was done with a population of cross-pollinated rubber tree progenies. It was set up in the regional research poles of the Agência Paulista de Agronegócios (Apta), in different rubber cropping regions of the state of São Paulo, Brazil, represented by the following municipalities: Jaú, Pindorama, and Votuporanga (Table 1).

Cross-pollinated progenies were obtained from parental clones from Southeast Asia germoplasm, introduced in 1952 at the experimental center at the Instituto Agronômico, Campinas, SP, Brazil (Table 2).

The experiments were set up in 2006, in a randomized block design, with 22 treatments (cross-pollinated progenies), six replicates, and ten plants per plot, placed in a single row with $1.5 \times 1.5 \mathrm{~m}$ spacing.

Rubber yield (g per tapping per plant) was obtained by the Hamaker Morris-Mann test (HMM), modified for three-year-old seedlings (Dijkman, 1951), based on the average dry rubber yield of 30 tappings per plant. The tapping panel was opened $15 \mathrm{~cm}$ above the ground, using $1 / 2 \mathrm{~S} \mathrm{~d} / 3$ tapping systems, with a total of 35 tappings, discarding the first five tapping samples which corresponded to the adaptation of the panel.

Table 1. Characteristics of the experimental sites, in three municipalities of the state of São Paulo, Brazil.

\begin{tabular}{lccc}
\hline Characteristic & Jaú & Pindorama & Votuporanga \\
\hline Latitude (S) & $22^{\circ} 17^{\prime}$ & $21^{\circ} 13^{\prime}$ & $20^{\circ} 25^{\prime}$ \\
Longitude (W) & $48^{\circ} 34^{\prime}$ & $48^{\circ} 56^{\prime}$ & $49^{\circ} 59^{\prime}$ \\
Altitude $(\mathrm{m})$ & 580 & 560 & 450 \\
Mean annual temperature $\left({ }^{\circ} \mathrm{C}\right)$ & 21.6 & 21.0 & 22.3 \\
Mean annual precipitation $(\mathrm{mm})$ & 1,344 & 1,390 & 1,480 \\
Soil type & Ferralsol & Acrisol & Lixisol \\
\hline
\end{tabular}

Table 2. Name of the parental clones introduced from Southeast Asian to the Instituto Agronômico in 1952, which originated the 22 evaluated progenies.

\begin{tabular}{lc}
\hline Progeny & Parental clone \\
\hline 1 & Tjir 1 \\
2 & AVROS 49 \\
3 & C 290 \\
4 & GT 127 \\
5 & AVROS 255 \\
6 & C 318 \\
7 & PB 49 \\
8 & AVROS 1328 \\
9 & AVROS 1126 \\
10 & AVROS 352 \\
11 & C 228 \\
12 & AVROS 363 \\
13 & RRIM 513 \\
14 & RRIM 600 \\
15 & C 256 \\
16 & PB 5/63 \\
17 & PR 107 \\
18 & C 297 \\
19 & GT 711 \\
20 & Tjir 16 \\
21 & PB 86 \\
22 & C 259 \\
\hline
\end{tabular}


The indication $1 / 2 \mathrm{~S}$ stands for a half-spiral cut, and $\mathrm{d} / 3$ indicates the interval between tappings, in this case, one tapping every three days.

Annual girth growth (cm per plant) was determined at $50 \mathrm{~cm}$ from the ground with a measuring tape. The analysis for individual variance was done according to the mathematical model that considers all the random effects, expressed by $Y_{i j k}=\mu+p_{i}+b_{j}+e_{i j}+d_{i j k}$, in which: $Y_{\mathrm{ijk}}$ is the observation related to plant $\mathrm{k}$ in the $\mathrm{j}$ replicate, in the i progeny; $\mu$ is the general mean; $p_{i}$ is the random effect of the $i^{\text {th }}$ progeny $(i=1,2, \ldots, p) ; b_{j}$ is the effect of the $j(j=1,2, \ldots, b)$ replicate; $e_{i j}$ is the effect of the random experimental error associated to the ij plot; $d_{i j k}$ is the random deviation inherent to plant $\mathrm{k}$ within the ij plot.

The variance estimates were obtained from the plot means in each location, following recommendations by Steel \& Torrie (1980), analyzed by the genetic statistical program Selegen (Resende, 2002).

Within plot variances $\left(\sigma_{d}^{2}\right)$ were calculated using individual plant data and averaging the individual plant square means.

Genetic and phenotypic parameters were estimated using the genetic statistical software Selegen - Reml/ Blup (Model 93).

Individual heritability in narrow sense was estimated as $\hat{\mathrm{h}}_{\mathrm{r}}^{2}=\hat{\sigma}_{\mathrm{a}}^{2} /\left(\hat{\sigma}_{\mathrm{a}}^{2}+\hat{\sigma}_{\mathrm{p}}^{2}+\hat{\sigma}_{\mathrm{e}}^{2}\right)$, in which: $\hat{\sigma}_{\mathrm{a}}^{2}$ is the additive genetic variance; $\hat{\sigma}_{\mathrm{p}}^{2}$ is the genetic variance among progenies; $\hat{\sigma}_{\mathrm{e}}^{2}$ is the environmental variance among plots.

Progeny mean heritability was calculated as $\hat{\mathrm{h}}_{\mathrm{mp}}^{2}=0.25 \hat{\sigma}_{\mathrm{a}}^{2} /\left(0.25 \hat{\sigma}_{\mathrm{a}}^{2}+\hat{\sigma}_{\mathrm{p}}^{2} / \mathrm{b}+\hat{\sigma}_{\mathrm{e}}^{2} / \mathrm{nb}\right)$, in which: $\mathrm{b}$ is the number of blocks; $n$ is the number of plots; $\hat{\sigma}_{a}^{2}$ is the additive genetic variance; $\hat{\sigma}_{\mathrm{p}}^{2}$ is the genetic variance among progenies; $\hat{\sigma}_{\mathrm{e}}^{2}$ is the environmental variance among plots.

Within plot additive heritability was calculated as $\hat{\mathrm{h}}_{\mathrm{ad}}^{2}=0.75 \hat{\sigma}_{\mathrm{a}}^{2} /\left(0.75 \hat{\sigma}_{\mathrm{a}}^{2}+\hat{\sigma}_{\mathrm{e}}^{2}\right)$, in which: $\hat{\sigma}_{\mathrm{p}}^{2}$ is the genetic variance among progenies; $\hat{\sigma}_{\mathrm{a}}^{2}$ is the additive genetic variance; $\hat{\sigma}_{\mathrm{e}}^{2}$ is the environmental variance among plots.

Individual genetic coefficient of variation was calculated as $\mathrm{CV}_{\mathrm{g}}(\%)=100\left(\hat{\sigma}_{\mathrm{a}}^{2} / \overline{\mathrm{x}}\right)^{0.5}$, in which: $\hat{\sigma}_{\mathrm{a}}^{2}$ is the additive genetic variance; and $\overline{\mathrm{x}}$ is the general mean.

Within plot environmental coefficient of variation was calculated as $\mathrm{CV}_{\mathrm{e}}(\%)=100\left[\left(\mathrm{c}^{2}+\hat{\sigma}_{\text {parc }}^{2} / \mathrm{n}\right)^{0.5} / \overline{\mathrm{x}}\right]$, in which: $\mathrm{c}^{2}$ is the plot coefficient of variation, $\hat{\sigma}_{\text {parc }}^{2}$ is the plot variance; $\overline{\mathrm{x}}$ is the general mean.
Selection gain (\%) was calculated as Gs $(\%)=100 \mathrm{Gs} / \overline{\mathrm{x}}$, in which: Gs is the genetic gain; and $\overline{\mathrm{x}}$ is the general mean

The multi-effect index (MEI) was used to estimate the selection gains (Resende, 2002) by the following expression:

$\hat{\mathrm{I}}=\hat{\mathrm{b}}_{1} \mathrm{Y}_{\mathrm{ijk}}+\left(\hat{\mathrm{b}}_{2}-\hat{\mathrm{b}}_{3}\right) \overline{\mathrm{Y}}_{\mathrm{i} .}+\left(\hat{\mathrm{b}}_{3}-\hat{\mathrm{b}}_{1}\right) \overline{\mathrm{Y}}_{\mathrm{ij} .}-\hat{\mathrm{b}}_{3} \overline{\mathrm{Y}}_{\mathrm{j} . \mathrm{f}}+\left(\hat{\mathrm{b}}_{3}-\hat{\mathrm{b}}_{2}\right) \overline{\mathrm{Y}}_{\ldots}$ in which: $\bar{Y}_{\text {... }}$ is the general mean of the experiment; $\mathrm{Y}_{\mathrm{ijk}}$ is the individual value; $\overline{\mathrm{Y}}_{\mathrm{i}}$ is the mean as a matrix in the experiment; $\bar{Y}_{\mathrm{ij} \text {. }}$ is the mean of the matrix in a determined block (plot mean); $\bar{Y}_{\mathrm{j} .}$ is the block mean; $\hat{b}_{1}=\hat{h}_{d}^{2}$ is the within plot heritability in the narrow sense; $\hat{h}_{\mathrm{d}}^{2}=(3 / 4) \hat{\sigma}_{\mathrm{A}}^{2} / \hat{\sigma}_{\mathrm{d}}^{2} ; \hat{\mathrm{b}}_{2}=\hat{\mathrm{h}}_{\mathrm{m}}^{2}$ is the heritability in the narrow sense of the matrices $\hat{\mathrm{h}}_{\mathrm{m}}^{2}=[(3+\mathrm{nb}) / 4 \mathrm{nb}] \hat{\sigma}_{\mathrm{A}}^{2} / \hat{\sigma}_{\mathrm{p}}^{2}+\hat{\sigma}_{\mathrm{e}}^{2} / \mathrm{b}+\hat{\sigma}_{\mathrm{d}}^{2} / \mathrm{n} ;$ and $\hat{b}_{3}=\hat{\mathrm{h}}_{\mathrm{p}}^{2}$ is the plot heritability in the narrow sense, in which $\hat{\mathrm{h}}_{\mathrm{p}}^{2}=(3 / 4 \mathrm{n}) \hat{\sigma}_{\mathrm{A}}^{2} / \hat{\sigma}_{\mathrm{e}}^{2}+\hat{\sigma}_{\mathrm{d}}^{2} / \mathrm{n}$.

The effective population $\left(\mathrm{N}_{\mathrm{e}}\right)$ was obtained according to Resende (2002) as $\mathrm{N}_{\mathrm{e}}=\left(4 \mathrm{~N}_{\mathrm{f}} \overline{\mathrm{k}}_{\mathrm{f}}\right) /\left[\overline{\mathrm{k}}_{\mathrm{f}}+3+\left(\hat{\sigma}_{\mathrm{kf}}^{2} / \overline{\mathrm{k}}_{\mathrm{f}}\right)\right]$, in which: $\bar{k}_{\mathrm{f}}$ is the mean number of selected individuals per matrix; $\hat{\sigma}_{\mathrm{kf}}^{2}$ is the variance of the number of selected individuals per matrix; $\mathrm{N}_{\mathrm{f}}$ is the number of selected matrices.

\section{Results and Discussion}

Significant mean square for progenies show that they differed as to annual girth growth and rubber yield, and indicate that selection can be made with data already from the first year of assessment, except for rubber yield in Jaú, where the mean square for progenies was not significant in the first year (Table 3). These results agree with those of Gonçalves et al. (2004a, 2009) and Costa et al. (2006).

The heritability values ranged from low to high for the evaluated variables (Table 4). Progeny mean heritability $\left(\hat{\mathrm{h}}_{\mathrm{mp}}^{2}\right)$ was higher than the individual heritability $\left(\hat{\mathrm{h}}_{\mathrm{r}}^{2}\right.$ and $\hat{\mathrm{h}}_{\mathrm{ad}}^{2}$ ); therefore, selection based on progeny mean would provide higher genetic gains than that based only on individuals. Gonçalves et al. (2005), in studies carried out in the same locations of the present one, with three-year-old progenies, and reported similar results, with greater $\left(\hat{h}_{m p}^{2}\right.$ than $\left.\hat{h}_{r}^{2}\right)$. These authors stated that high heritability estimates, together with a great variation within population, makes it more efficient to select for productive and vigorous progenies. Silva et al. (2012) also reported progeny mean-based heritability greater than individual

Pesq. agropec. bras., Brasília, v.48, n.4, p.411-416, abr. 2013 DOI: $10.1590 / \mathrm{S} 0100-204 X 2013000400009$ 
and within progeny heritabilities, for rubber yield and annual girth growth. Therefore, selecting by progeny mean seems to be a sound strategy to increase the genetic gain in rubber tree.

The selective-accuracy $\left(\hat{\mathrm{r}}_{\hat{a} \mathrm{a}}\right)$ values were greater than $80 \%$, within the indicated standard for the first and intermediate steps of a breeding program (Resende, 2007). High-accuracy values are advantageous because they can provide high genetic gain values and increase selecting efficiency of progenies.

The coefficient of genetic variation $(\mathrm{CVg} \%)$ and the experimental coefficient of variation $(\mathrm{CVe} \%)$ (Table 4) were low, but within the expected range for rubber. Higher values were reported by Gonçalves et al. (2004b) and Gouvêa et al. (2012). The relative variation index $(\mathrm{CVr})$ showed very high values, greater than 1.0 in some cases, indicating high genetic variability for the evaluated variables, in all the years and locations. These values also indicate a favorable situation for selection.

Selecting $13.63 \%$ of the best progenies led to high selection gains, estimated with MEI, for rubber

Table 3. Individual analysis for annual girth growth $(\mathrm{cm}$ per plant) and dry rubber yield (g per tapping per plant), of 22 rubber tree progenies assessed for three years, in Jaú, Pindorama, and Votuporanga, São Paulo state, Brazil, 2006.

\begin{tabular}{|c|c|c|c|c|}
\hline \multirow[t]{2}{*}{ Variable } & \multirow[t]{2}{*}{ Year } & \multicolumn{3}{|c|}{ Mean square } \\
\hline & & Progeny & Residual & Within plot \\
\hline & \multicolumn{4}{|c|}{ Jaú } \\
\hline \multirow{4}{*}{ Annual girth growth } & 1 & $2.05 * *$ & 0.36 & 0.98 \\
\hline & 2 & $0.87 * *$ & 0.39 & 2.14 \\
\hline & 3 & $10.70 * *$ & 2.45 & 15.27 \\
\hline & 1 & $0.02^{\mathrm{ns}}$ & 0.02 & 0.12 \\
\hline \multirow[t]{4}{*}{ Rubber yield } & 2 & $0.12 * *$ & 0.06 & 0.44 \\
\hline & 3 & $0.30 * *$ & 0.12 & 0.92 \\
\hline & \multicolumn{4}{|c|}{ Pindorama } \\
\hline & 1 & $1.02 * *$ & 0.17 & 0.71 \\
\hline \multirow[t]{3}{*}{ Annual girth growth } & 2 & $1.94 *$ & 1.04 & 3.49 \\
\hline & 3 & $20.37 * *$ & 3.31 & 25.82 \\
\hline & 1 & $0.36 * *$ & 0.04 & 0.29 \\
\hline \multirow[t]{4}{*}{ Rubber yield } & 2 & $0.52 * *$ & 0.05 & 0.39 \\
\hline & 3 & $0.58 * *$ & 0.09 & 0.69 \\
\hline & \multicolumn{4}{|c|}{ Votuporanga } \\
\hline & 1 & $1.45 * *$ & 0.23 & 0.87 \\
\hline \multirow[t]{3}{*}{ Annual girth growth } & 2 & $1.88 * *$ & 0.46 & 3.15 \\
\hline & 3 & $22.99 * *$ & 2.17 & 20.22 \\
\hline & 1 & $0.08 * *$ & 0.01 & 0.13 \\
\hline \multirow[t]{2}{*}{ Rubber yield } & 2 & $0.14 * *$ & 0.02 & 0.24 \\
\hline & 3 & $0.26^{* *}$ & 0.06 & 0.63 \\
\hline
\end{tabular}

${ }^{n s}$ Nonsignificant. *and**Significant by the $\mathrm{F}$ test, at 5 and $1 \%$ probability. yield, using data from the three early tests (Table 5). However, low selection gains were observed in the first year of production in Jaú $(3,92 \%)$, which was already expected since the observed heritabilities in this period (Table 4) were also low $\left(\hat{\mathrm{h}}^{2}{ }_{\mathrm{mp}}=0,08\right)$. Progeny selection in Jaú is recommended only from the third production year, when heritability value becomes high $(59.52 \%)$.

Genetic gains are based on the general mean of each year. In the present study, the improved mean was greater than the general mean, in all the locations and tests; thus, selecting the three best progenies would increase yield up to $1.28 \mathrm{~g}$ per plant. Because of the genetic gain increases over the assessment years, selection is recommended only at the end of the third test, in order to make the breeding programs more efficient.

The annual girth growth had high selection gains, estimated with MEI, in all assessed years and locations

Table 4. Estimates of genetic parameters for annual girth growth and rubber yield of 22 rubber tree progenies assessed for three years, in three locations, in the state of São Paulo, Brazil.

\begin{tabular}{|c|c|c|c|c|c|c|c|c|}
\hline \multirow[t]{2}{*}{ Variable } & \multirow[t]{2}{*}{ Year } & \multicolumn{7}{|c|}{ Estimates } \\
\hline & & $\hat{\mathrm{h}}_{\mathrm{r}}^{2}$ & $\hat{\mathrm{h}}_{\mathrm{mp}}^{2}$ & $\hat{\mathrm{h}}_{\mathrm{ad}}^{2}$ & $\hat{\mathrm{r}}_{\mathrm{a} a \mathrm{a}}$ & $\mathrm{CVg}$ & $\mathrm{CVr}$ & $\mathrm{CVe}$ \\
\hline \multirow{4}{*}{$\begin{array}{l}\text { Annual } \\
\text { girth } \\
\text { growth }\end{array}$} & \multicolumn{8}{|c|}{ Jaú } \\
\hline & 1 & $0.73 \pm 0.15$ & 0.82 & 0.86 & 0.91 & 12.13 & 0.88 & 13.82 \\
\hline & 2 & $0.13 \pm 0.06$ & 0.55 & 0.11 & 0.74 & 10.35 & 0.45 & 22.74 \\
\hline & 3 & $0.31 \pm 0.09$ & 0.77 & 0.27 & 0.88 & 10.50 & 0.74 & 14.05 \\
\hline \multirow{3}{*}{$\begin{array}{l}\text { Rubber } \\
\text { yield }\end{array}$} & 1 & $0.01 \pm 0.03$ & 0.08 & 0.01 & 0.28 & 3.43 & 0.12 & 29.23 \\
\hline & 2 & $0.09 \pm 0.08$ & 0.50 & 0.07 & 0.71 & 10.34 & 0.41 & 24.95 \\
\hline & 3 & $0.12 \pm 0.08$ & 0.58 & 0.09 & 0.76 & 13.55 & 0.48 & 28.41 \\
\hline \multirow{4}{*}{$\begin{array}{l}\text { Annual } \\
\text { girth } \\
\text { growth }\end{array}$} & \multicolumn{8}{|c|}{ Pindorama } \\
\hline & 1 & $0.60 \pm 0.12$ & 0.84 & 0.60 & 0.91 & 8.91 & 0.92 & 9.67 \\
\hline & 2 & $0.14 \pm 0.06$ & 0.47 & 0.13 & 0.68 & 11.21 & 0.38 & 29.33 \\
\hline & 3 & $0.39 \pm 0.10$ & 0.84 & 0.33 & 0.92 & 12.16 & 0.93 & 13.13 \\
\hline \multirow{3}{*}{$\begin{array}{l}\text { Rubber } \\
\text { yield }\end{array}$} & 1 & $0.59 \pm 0.14$ & 0.88 & 0.54 & 0.94 & 33.29 & 1.13 & 29.48 \\
\hline & 2 & $0.64 \pm 0.14$ & 0.89 & 0.59 & 0.95 & 32.78 & 1.19 & 27.41 \\
\hline & 3 & $0.40 \pm 0.11$ & 0.83 & 0.35 & 0.91 & 23.11 & 0.91 & 25.38 \\
\hline \multirow{4}{*}{$\begin{array}{l}\text { Annual } \\
\text { girth } \\
\text { growth }\end{array}$} & \multicolumn{8}{|c|}{ Votuporanga } \\
\hline & 1 & $0.67 \pm 0.14$ & 0.84 & 0.70 & 0.92 & 11.24 & 0.95 & 11.85 \\
\hline & 2 & $0.27 \pm 0.09$ & 0.76 & 0.23 & 0.87 & 9.16 & 0.72 & 12.76 \\
\hline & 3 & $0.58 \pm 0.13$ & 0.91 & 0.51 & 0.95 & 11.00 & 1.27 & 8.69 \\
\hline \multirow{3}{*}{$\begin{array}{l}\text { Rubber } \\
\text { yield }\end{array}$} & 1 & $0.34 \pm 0.11$ & 0.84 & 0.27 & 0.91 & 24.06 & 0.93 & 25.87 \\
\hline & 2 & $0.29 \pm 0.10$ & 0.82 & 0.24 & 0.91 & 23.60 & 0.87 & 27.11 \\
\hline & 3 & $0.19 \pm 0.08$ & 0.75 & 0.15 & 0.87 & 19.91 & 0.71 & 28.21 \\
\hline
\end{tabular}

$\hat{\mathrm{h}}_{\mathrm{r}}^{2}$, individual heritability in the narrow sense; $\hat{\mathrm{h}}_{\mathrm{mp}}^{2}$, progeny mean heritability; $\hat{\mathrm{h}}_{\mathrm{ad}}^{2}$, within plot additive heritability; $\hat{\mathrm{r}}_{\mathrm{a} a}$, accuracy; CVg $(\%)$, coefficient of genetic variation; $\mathrm{CVr}$, index of relative variation $(\mathrm{CVg} / \mathrm{CVe})$; and $\mathrm{CVe}(\%)$, coefficient of experimental variation. 
(Table 6). Due to the high genetic gain obtained with data already from the first year, the most vigorous progenies can be selected at the beginning of the breeding program. Early selection can reduce rubber tree breeding cycle, which is very long, taking from 25 to 30 years to reach the final results. The positive selection gains obtained in all the assessment years and locations allows for a more reliable early selection. The values reported here are compatible with other studies, such as those by Gonçalves et al. (2004b), which used a different methodology.

A more effective selection must take yield into consideration and account for the performance of

Table 5. Selection gains, new means, and effective population size $(\mathrm{Ne})$ of selected individuals by the multi-effect index method, for rubber yield ( $\mathrm{g}$ per tapping per plant) of 22 progenies assessed for three years, in Jaú, Pindorama, and Votuporanga, in the state of São Paulo, Brazil.

\begin{tabular}{|c|c|c|c|c|c|}
\hline Year & Progeny ${ }^{(1)}$ & Gains & New mean & $\mathrm{Ne}$ & Mean \\
\hline \multicolumn{6}{|c|}{ Jaú } \\
\hline & 6 & 0.03 & 0.54 & 1.00 & \\
\hline \multirow[t]{3}{*}{1} & 19 & 0.02 & 0.53 & 2.00 & 0.51 \\
\hline & 22 & 0.02 & 0.53 & 3.00 & \\
\hline & 19 & 0.33 & 1.30 & 1.00 & \\
\hline \multirow[t]{3}{*}{2} & 15 & 0.30 & 1.28 & 2.00 & 0.98 \\
\hline & 19 & 0.29 & 1.27 & 2.48 & \\
\hline & 17 & 0.84 & 2.10 & 1.00 & \\
\hline \multirow[t]{2}{*}{3} & 19 & 0.76 & 2.04 & 2.00 & 1.26 \\
\hline & 19 & 0.75 & 2.01 & 2.48 & \\
\hline \multicolumn{6}{|c|}{ Pindorama } \\
\hline \multirow{3}{*}{1} & 20 & 1.37 & 2.06 & 1.00 & \\
\hline & 20 & 1.35 & 2.04 & 1.60 & \\
\hline & 20 & 1.30 & 2.01 & 2.00 & 0.69 \\
\hline \multirow{3}{*}{2} & 4 & 1.91 & 2.76 & 2.76 & \\
\hline & 15 & 1.77 & 2.62 & 2.61 & \\
\hline & 20 & 1.71 & 2.56 & 2.56 & 0.85 \\
\hline \multirow{3}{*}{3} & 19 & 1.70 & 2.93 & 1.00 & \\
\hline & 5 & 1.62 & 2.84 & 2.00 & \\
\hline & 15 & 1.54 & 2.76 & 3.00 & 1.23 \\
\hline \multicolumn{6}{|c|}{ Votuporanga } \\
\hline \multirow{3}{*}{1} & 18 & 0.95 & 1.40 & 1.00 & \\
\hline & 18 & 0.85 & 1.29 & 1.60 & \\
\hline & 18 & 0.78 & 1.23 & 2.00 & 0.45 \\
\hline \multirow{3}{*}{2} & 17 & 1.01 & 1.59 & 1.00 & \\
\hline & 18 & 0.95 & 1.53 & 2.00 & \\
\hline & 12 & 0.90 & 1.46 & 3.00 & 0.58 \\
\hline \multirow{3}{*}{3} & 3 & 1.20 & 2.11 & 1.00 & \\
\hline & 18 & 1.19 & 2.09 & 2.00 & \\
\hline & 17 & 1.13 & 2.04 & 3.00 & 0.90 \\
\hline
\end{tabular}

(1)Progeny numbers related to identification in Table 2. other variables that contribute to yield increase, especially the annual girth growth gain, which is related to plant vigor.

The effective population size was in agreement with the number of selected progenies (three), indicating that they were not related, thus ensuring the genetic variability of the population. The mean inbreeding coefficient was high with $\mathrm{F}=\left[1 /(2 \mathrm{Ne})^{*} 100\right]=17 \%$, but this value can be reduced by increasing the number of selected individuals. Arantes et al. (2010) reported endogamy coefficient values lower $(\mathrm{F}=2.88 \%)$ than those observed in the present study, selecting the 20 best rubber tree progenies for rubber yield.

Table 6. Selection gains, new means, and effective populational size $(\mathrm{Ne})$ of selected individuals by the multi-effect index, for annual girth growth ( $\mathrm{cm}$ per plant) of 22 progenies assessed for three years, in Jaú, Pindorama, and Votuporanga, in the state of São Paulo, Brazil.

\begin{tabular}{|c|c|c|c|c|c|}
\hline Year & Progeny ${ }^{(1)}$ & Gains & New mean & $\mathrm{Ne}$ & Mean \\
\hline \multicolumn{6}{|c|}{ Jaú } \\
\hline \multirow{3}{*}{1} & 13 & 2.55 & 6.92 & 1.00 & \\
\hline & 21 & 2.55 & 6.92 & 2.00 & \\
\hline & 21 & 2.54 & 6.91 & 2.48 & 4.37 \\
\hline \multirow{3}{*}{2} & 1 & 0.83 & 3.57 & 1.00 & \\
\hline & 19 & 0.83 & 3.57 & 2.00 & \\
\hline & 4 & 0.81 & 3.56 & 3.00 & 2.75 \\
\hline \multirow{3}{*}{3} & 14 & 4.93 & 16.09 & 1.00 & \\
\hline & 21 & 4.74 & 15.90 & 2.00 & \\
\hline & 14 & 4.62 & 15.78 & 2.48 & 11.16 \\
\hline \multicolumn{6}{|c|}{ Pindorama } \\
\hline \multirow{3}{*}{1} & 18 & 3.77 & 8.00 & 1.00 & \\
\hline & 12 & 2.78 & 7.01 & 2.00 & \\
\hline & 12 & 2.44 & 6.67 & 2.48 & 4.23 \\
\hline \multirow{3}{*}{2} & 3 & 4.18 & 7.66 & 1.00 & \\
\hline & 9 & 2.70 & 6.17 & 2.00 & \\
\hline & 9 & 2.14 & 5.61 & 2.48 & 3.47 \\
\hline \multirow{3}{*}{3} & 10 & 6.53 & 20.39 & 1.00 & \\
\hline & 5 & 6.50 & 20.36 & 2.00 & \\
\hline & 1 & 6.48 & 20.34 & 3.00 & 13.86 \\
\hline \multicolumn{6}{|c|}{ Votuporanga } \\
\hline \multirow{3}{*}{1} & 11 & 3.15 & 7.17 & 1.00 & \\
\hline & 17 & 3.04 & 7.05 & 2.00 & \\
\hline & 1 & 2.79 & 6.81 & 3.00 & 4.01 \\
\hline \multirow{3}{*}{2} & 14 & 1.89 & 7.22 & 1.00 & \\
\hline & 3 & 1.86 & 7.18 & 2.00 & \\
\hline & 21 & 1.83 & 7.15 & 3.00 & 5.32 \\
\hline \multirow{3}{*}{3} & 5 & 9.52 & 26.45 & 1.00 & \\
\hline & 5 & 9.40 & 26.33 & 1.60 & \\
\hline & 18 & 9.26 & 26.19 & 2.48 & 16.93 \\
\hline
\end{tabular}

(1)Progeny numbers related to identification in Table 2. 


\section{Conclusions}

1. Genetic variability for the studied variables in rubber tree progenies can be detected in young plants, which indicates favorable conditions for early selection.

2. Selection is more efficient when based on the progeny mean than when based only on individuals.

3. Early selection can be made on rubber tree progenies using the genetic gains estimated with multi-effects index.

\section{Acknowledgments}

To Fundação de Amparo à Pesquisa do Estado de São Paulo (Fapesp), for financial support and scholarship.

\section{References}

ARANTES, F.C.; GONÇALVES, P. de S.; SCALOPPI JUNIOR, E.J.; MORAES, M.L.T. de; RESENDE, M.D.V. de. Ganho genético com base no tamanho efetivo populacional de progênies de seringueira. Pesquisa Agropecuária Brasileira, v.45, p.1419-1424, 2010. DOI: 10.1590/S0100-204X2010001200012.

COSTA, R.B. da; RESENDE, M.D.V. de; GONÇALVES, P. de S.; CHICHORRO, J.F.; ROA, R.A.R. Variabilidade genética e seleção para caracteres de crescimento da seringueira. Bragantia, v.67, p.299-305, 2008. DOI: 10.1590/ S0006-87052008000200005.

COSTA, R.B. da; RESENDE, M.D.V. de; GONÇALVES, P. de S.; REGO, F.L.H.; CONTINI, A.Z.; ROA, R.A.R. Genetic evaluation of Hevea brasiliensis [(Willd ex Adr. de Juss.) Müell. Arg.] for juvenile vigour using the Reml/Blup method. Floresta e Ambiente, v.12, p.8-14, 2006.

DIJKMAN, M. J. Hevea: thirty years of research in Far East Florida. Miami: University of Miami, 1951. 329p.

FREITAS, M.L.M.; SEBBENN, A.M.; MORAIS, E.; ZANATTO, A.C.S.; VERARDI, C.K.; PINHEIRO, A.N. Parâmetros genéticos em progênies de polinização aberta de Cordia trichotoma (Vell.) ex Steud. Revista do Instituto Florestal, v.18, p.95-102, 2006.

GONÇALVES, P. de S.; BORTOLETTO, N.; COSTA, R.B. da; SILVA, M. de A.; CARDINAL, Á.B.B.; GOUVÊA, L.R.L. Estimates of annual genetic parameters and expected gains in the second cycle of Hevea genotype selection. Crop Breeding and Applied Biotechnology, v.4, p.416-421, 2004a.
GONÇALVES, P. de S.; CARDINAL, A.B.B.; COSTA, R.B. da; BORTOLETTO, N.; GOUVÊA, L.R.L. Genetic variability and selection for laticiferous system characters in Hevea brasiliensis. Genetics and Molecular Biology, v.28, p.414-422, 2005. DOI: 10.1590/S1415-47572005000300014.

GONÇALVES, P. de S.; MARTINS, A.L.M.; BORTOLETTO, N.; SAES, L.A. Selection and genetic gains for juvenile trains in progenies of Hevea in São Paulo state, Brazil. Genetics and Molecular Biology, v.27, p.207-214, 2004b. DOI: 10.1590/ S1415-47572004000200014.

GONÇALVES, P. de S.; MORAES, M.L.T. de; SILVA, M. de A.; GOUVÊA, L.R.L.; AGUIAR, A.T. da E.; COSTA, R.B. Prediction of Hevea progeny performance in the presence of genotype-environment interaction. Brazilian Archives of Biology and Technology, v.52, p.25-33, 2009. DOI: 10.1590/ S1516-89132009000100004

GOUVÊA, L.R.L.; SILVA, G.A.P.; VERARDI, C.K.; SILVA, J.Q.; SCALOPPI-JUNIOR, E.J.; GONÇALVES, P. de S. Temporal stability of vigor in rubber tree genotypes in the pre- and post-tapping phases using different methods. Euphytica, v.186, p.625-634, 2012. DOI: 10.1007/s10681-012-0688-y.

RESENDE, M.D.V. de. Genética biométrica e estatística no melhoramento de plantas perenes. Brasília: Embrapa Informação Tecnológica; Colombo: Embrapa Florestas, 2002. 975p.

RESENDE, M.D.V. de. Matemática e estatística na análise de experimentos e no melhoramento genético. Colombo: Embrapa Florestas, 2007. 561p.

RESENDE, M.D.V. de; FERNANDES, J.S.C.; SIMEÃO, R.M. Blup individual multivariado em presença de interação genótipo $\mathrm{x}$ ambiente para delineamentos experimentais repetidos em vários ambientes. Revista de Matemática e Estatística, v.17, p.209-228, 1999.

RESENDE, M.D.V. de; HIGA, A.R. Estimação de valores genéticos no melhoramento de Eucalyptus: seleção em um caráter com base em informações do indivíduo e de seus parentes. Boletim de Pesquisa Florestal, v.28/29, p.11-35, 1994a.

RESENDE, M.D.V. de; HIGA, A.R. Maximização da eficiência da seleção em testes de progênies de Eucalyptus através da utilização de todos os efeitos do modelo matemático. Boletim de Pesquisa Florestal, v.28/29, p.37-55, 1994b.

SILVA, G.A.P.; GOUVÊA, L.R.L.; VERARDI, C.K.; RESENDE, M.D.V. de; SCALOPPI JUNIOR, E.J.; GONÇALVES, P. de S. Genetic parameters and correlation in early measurement cycles in rubber trees. Euphytica, v.189, p.343-350, 2012. DOI: 10.1007/ s10681-012-0751-8.

STEEL, R.G.D.; TORRIE, J.H. Principles and procedures of statistics: a biometrical approach. $2^{\text {nd }}$ ed. New York: McGraw-Hill, 1980. 633p.

$\overline{\text { Received on July 16, } 2012 \text { and accepted on March 28, } 2013}$

Pesq. agropec. bras., Brasília, v.48, n.4, p.411-416, abr. 2013

DOI: 10.1590/S0100-204X2013000400009 